apparently cover the export of nuclear reactors, focusing rather on uranium enrichment, the reprocessing of nuclear fucl and the production of heavy water. The precise details remain a secret, however, though the nuclear countries may want explicit undertakings from their customers that they will not use nuclear material supplied for civil purposes to produce nuclear weapons.

It is understood that each party to the agreement will simply inform the others of its intentions to observe the agreed safeguards, which are expected to be presented at the meeting in Vienna early next year of the Board of Governors of the International Atomic Fnergy Agency (IAEA).

There may also be a proposal at the meeting to make more countries subscribe to the IAEA's existing safeguards. At present they apply only to countries which are signatories to the nuclear Non-proliferation Treaty, but the hope is that countries like Brazil, Egypt, Israel, India and Pakistan-all of which have not signed the treatymight state their intentions more specifically if they are given the clear option of agreeing to the safeguards.

It is also hoped that other countries with the potential to become exporters, like Sweden, Holland and South Africa, will adopt the new code just agreed by the Group of Seven. But whatever the outcome, a central problem remains: it is not certain that a particular nuclear experiment-such as an underground explosion-can be established, to the satisfaction of the group or anyone else, as essential to the development of nuclear energy, rather than a preliminary step to the manufacture of a nuclear weapon. Which, given India's case, is where the Nuclear Suppliers Group came in.

\section{Moves to keep the dragon}

Ir now seems that the UK-based OECD Dragon High Temperature Reactor Project, the continued existence of which has been in doubt for the past few months, will carry on for at least nine months. Compromise proposals made last week in Brussels, but subject to clarification in further meetings this week, mean that there will be time for the Dragon Board of Management to sort out the bones of an agreement with the US Energy Research and Development Administration (ERDA), which has expressed interest in using the Dragon reactor at Winfrith, Dorset.

The villain of the piece is widely acknowledged to be the UK. The De- partment of Encrgy, presumably egged on by the Treasury, has in the recent past expressed complete reluctance to the idea of contributing any more money to a project which it now sees as well outside the mainstream of British reactor development-at present centred on the 'Steamer' pressuretube reactor, and, in the longer term, the Fast Breeder Reactor.

Back in September, formal steps had to be taken to run the project down because there seemed no prospect of agreement about future funding. Then the UK relented a little by agreeing to a stay of execution until the end of March next year. Now West Germany has apparently convinced the EEC to see that deadline extended by a further six months.

The EEC is closely involved because Euratom is one of the participants in the project; smaller participating countries like Austria, Switzerland and Sweden have said that they are happy to go along with the German proposal, so Brussels calls the tune. What remains to be clarified this week is the precise meaning of a UK suggestion to the effect that satisfactory financial arrangements must be on the horizon by the end of March.

Dr L. R. Shepherd, chief executive of the Dragon project, said last week that he hoped the UK would adopt a reasonable approach to the problems, and not stick too rigidly to its argument that Dragon is no longer of any direct use to the UK's nuclear programme. Whatever mistakes the UK may have made in its Advanced Gascooled Reactor programme, he said, it still has unsurpassed experience of gas-cooled reactors, and it would be folly to opt out at a time when the ERDA is looking favourably on collaboration.

Quite apart from that, the United Kingdom Atomic Energy Authority does quite nicely out of Dragon because, even now, it gets back from the project more money in payment for services and so on at its Winfrith site than the UK pays out to be a member of the Dragon project. If ERDA makes a contribution, and the UK pays less as a consequence, the situation will look even more attractive.

That said, however, it needs to be remembered that ERDA is rather unsure of its position at the moment because General Atomic in the United States has been busily losing all its commercial orders for high temperature reactors during the past few months-partly because electricity utilities in the USA are short of money and partly because the anti-nuclear lobby has been so conspicuously successful in getting its message across.

\section{Indians ask for more nuclear power}

\section{Jullundur}

India has yet to display the trends apparent in small-town communities in the United States which react strongly to moves to establish nuclear power plants in their areas out of concern over possible radiation hazards. On the sub-continent nuclear energy continues to rate highly. Most people consider it prestigious and modern.

With the number of reactors in India still relatively small, most people are both unaware and unconcerned about the hazardous aspects of nuclear energy. In fact, one of the most persistent gripes that eastern states have had is that the Atomic Energy Commission (AEC) has time and again refused to concede their 'just' demand for a nuclear power station in their regions. The state of West Bengal has actually made it a cause, leading a vigorous battle on the issue.

The AEC's long-held view is that nuclear power generation in the eastern region, where most of the country's coal mines are located, is neither necessary nor economically viable. An AEC study concluded that nuclear power within $800 \mathrm{~km}$ of a coal pit-head would be uneconomical, and two further detailed studies carried out by the Central Planning Commission suggested that there was no need for a nuclear power station in the eastern region.

Not to be deterred, the West Bengal government pressed its demand. Then came the oil crisis, which pushed up all prices, including that of coal. Freight rates also went up, making coal haulage more expensive, and the West Bengal government pressed its claim for nuclear power even more vigorously.

The central government may finally have to yield to regional pressure. An cfficial of the West Bengal government has claimed that studies carried out by the AEC in 1973-74 had reduced the break-even radius for nuclear power to only $300 \mathrm{~km}$, with the "changed economics of coal", and the new studies would further reduce the radius to less than $150 \mathrm{~km}$.

If this happens, it would help "justify" the West Bengal demand for a nuclear power station, because the site the state had proposed for the purpose is situated some $250 \mathrm{~km}$ from the Asansol coal mines. Although West Bengal is an industrially advanced state by comparison with others which already have nuclear power, it remains debatable whether there is much to iustify its continued insistence on having a nuclear power station-whatever the economics of coal. 